Bull. Mater. Sci., Vol, 17, No. 6, November 1994, pp. 643-662. (C) Printed in India.

\title{
Some new results in thermomechanical processing of microalloyed steels
}

\author{
RAMEN DATTA and SANAK MISHRA \\ R \& D Centre for Iron and Steel, Steel Authority of India Ltd., Ranchi 834002 , India
}

\begin{abstract}
In recent times, efforts have been directed towards a better understanding of the mechanisms associated with deformation and restoration of austenite during continuous multipass hot rolling of microalloyed steels. The correspondence between the condition of austenite before transformation and the resultant microstructure upon cooling holds the key to the attainment of interesting properties.

In the present paper, some results obtained on the deformation of austenite in a microalloyed steel, using a hot compression machine, are presented. Here, the idea was to simulate actual plate rolling or hot strip rolling conditions and study the evolution of microstructure at different stages of the hot deformation process i.e. after precise reductions at given strain rate and temperature of deformation.

The paper further discusses recent results obtained by us on the influence of hot deformation parameters (strain, finish rolling temperature, temperature of deformation) and cooling rates (air cooling, spray water cooling) on the microstructure of microalloyed steel. The precise conditions leading to the evolution of acicular ferrite and bainitic microstructures have been identified. New information on the influence of short tempering treatments (15 min at 550,600 and $650^{\circ} \mathrm{C}$ ) on the microstructure and properties of a microalloyed steel are also outlined.
\end{abstract}

Keywords. Thermomechanical processing; microalloyed; acicular; bainite; tempering.

\section{Introduction}

During a typical hot working operation of C-Mn steel, the austenite phase is subjected to hardening and softening (restoration) processes. Hypothetically, the restoration processes can occur dynamically (within the roll gap) or statically (between two passes). As a result of strain rates usually ranging from $10 \mathrm{~s}^{-1}$ for plate rolling and up to $200 \mathrm{~s}^{-1}$ for hot strip rolling, the time available for dynamic recrystallization to occur is exceedingly small. Hence the dominant operative mechanism of austenite conditioning is static recrystallization.

The general conditions for recrystallization in metals and alloys have been examined, explained and summarized in detail by Beck (1954). In the present case of austenite, the factors that may affect recrystallization behaviour can be categorized as (i) strain, (ii) strain rate, (iii) temperature of deformation, (iv) initial grain size, (v) chemical composition and (vi) crystalline defects within the austenite. Additionally, microalloying elements (MAE) such as $\mathrm{Nb}, \mathrm{V}$ and $\mathrm{Ti}$ have been shown to have a controlling influence on the recrystallization behaviour of austenite, either while in solid solution or as second phase precipitates. This can be understood by the way the MAE first affects the critical temperature for onset of grain coarsening $\left(T_{\mathrm{Gc}}\right)$ during reheating and subsequently the temperature at which the recrystallization process virtually stops $\left(T_{\mathrm{RXN}}\right)$ during hot deformation of austenite. To minimize abnormal grain growth of the austenite, the reheating temperature is kept below 
the grain coarsening temperature. The most pronounced effect of MAE (especially $\mathrm{Nb}$ ), however, is the retardation of the recrystallization process (Irani et al 1967; Jones and Rothwell 1968; Jonas and Weiss 1979). The phenomenon of retardation has been attributed to (i) the solute drag effect, originally proposed by Lucke and associates (Lucke and Detert 1957; Lucke and Stuwe 1963), (ii) the strain induced precipitation of fine $\mathrm{Nb}(\mathrm{CN})$ (Rothwell 1972; Le Bon et al 1975; Sekine and Maruyama 1976) and (iii) a combination of the two. The retardation effect leads to a temperature range of 'non-recrystallization'.

Microalloyed elements such as $\mathrm{Nb}$ increase the critical amount of reduction $\left(R_{\text {crit }}\right)$ required for complete recrystallization of the austenite. Thus at a given temperature of deformation, $R_{\text {crit }}$ value for a $\mathrm{Nb}$ steel is significantly higher than that of a plain C-Mn steel (Tanaka et al 1977). A concurrent increase in $T_{\mathrm{RXN}}$ enables a wider temperature range of deformation of austenite in the non-recrystallization region. Deformation below $T_{\mathrm{RXN}}$ results in fully unrecrystallized (pancaked) austenite grains, whereas above this temperature, it results in the formation of partially or fully recrystallized austenite grains (Cuddy 1982). In addition, such a definition of $T_{\mathrm{RXN}}$ helps to differentiate between two different thermomechanical processes: conventional controlled rolling (CCR) (Tanaka 1985) and recrystallization controlled rolling (RCR) (Zheng et al 1984). Deformation below $T_{\mathrm{RXN}}$ is representative of the CCR process whereas deformation above $T_{\mathrm{RXN}}$ represents the RCR process.

The condition of the austenite prior to and at the time of transformation influences the final ferrite microstructure and properties. One important factor in this regard is its ability to provide nucleation sites for ferrite during transformation on cooling. According to Fukuda et al (1977), there are two modes of $\gamma \rightarrow \alpha$ transformation, viz. types 1 and 2 . Type 1 describes transformation from recrystallized $\gamma$ at the grain boundaries. Type 2 on the other hand is the transformation mode from unrecrystallized $\gamma$, where ferrite nucleation occurs predominantly at grain interiors (deformation bands and incoherent twin boundaries), but also at grain boundaries. Although Fukuda et al (1977) do not mention the role of transition bands specifically, it is the view of the present authors that nucleation at transition bands must be a very significant factor. In any case, the hot rolling parameters need to be controlled such that a large number of planar crystalline defects $\left(S_{v}\right.$, as defined by Underwood (1968)) are retained in the austenite, which subsequently upon transformation lead to a fine ferrite grain size.

The critical features of a conventional thermomechanical process are (i) suitable selection of alloy chemistry, (ii) choice of slab reheating temperature, (iii) degree and distribution of deformation in the $\gamma$-recrystallization zone, (iv) deformation in the $\gamma$-non-recrystallization zone and (v) controlled cooling. The slab reheating temperature determines the initial grain size and distribution of MAE (solid solution or precipitates). The most important hot deformation parameters are the total reduction below recrystallization temperature $\left(T_{\mathrm{RXN}}\right)$ and the finish rolling temperature (FRT). Accelerated cooling after finish rolling helps in attaining a wide array of microstructures and associated mechanical. properties, since it affects the transformation and precipitation processes. Thus a slow cooling rate $\left(-3^{\circ} \mathrm{C} / \mathrm{s}\right)$ leads to the conventional ferrite-pearlite structure while a faster cooling rate $\left(3-15^{\circ} \mathrm{C} / \mathrm{s}\right)$ leads to formation of fine bainitic structures. Most accelerated cooling processes, in practice, are applied interruptedly through the transformation temperature range, typically $800-500^{\circ} \mathrm{C}$, followed by air cooling to room temperature. 
The present set of investigations were aimed at (i) bridging the gaps in our understanding of TMCP and (ii) to utilize the available state-of-art knowledge for the design and development of new microstructures. In line with the above, controlled hot deformation experiments were conducted to study the evolution of microstructure at different stages of a typical thermomechanical process. Further, studies were carried out on a 150-ton capacity experimental hot rolling mill to establish the processing conditions leading to the successful development of acicular ferrite and bainitic microstructures in microalloyed steels. The microstructural changes associated with short tempering treatments on microalloyed steels were also investigated.

\section{Experimental}

\subsection{Material composition}

The starting materials used for the present studies (conducted in four parts) are as follows:

(A) Hot deformation of austenite: The composition (wt\%) of the steel was: C-0.06, Mn-1.35, S-0.01, P-0.013, Si-0.31, Al-0.03, Ti-0.08 and B-0.0007.

(B) Acicular ferrite microstructure: A plain-Ti steel having the following composition (wt\%): C-0.06, Mn-1.35, S-0.01, P-0.013, Si-0.25, Al-0.04 and Ti-0.01, was used.

(C) Bainite microstructure: The chemical composition was the same as that used for hot deformation studies.

(D) Tempering studies: The chemical composition (wt\%) of the steel investigated was: $\mathrm{C}-0.11, \mathrm{Mn}-0.88, \mathrm{~S}-0.016, \mathrm{P}-0.02, \mathrm{Al}-0.05, \mathrm{Cu}-0.38, \mathrm{Cr}-0.40, \mathrm{Nb}-0.05$ and $\mathrm{V}-0.04$. (The steel was alloyed with copper $(0.38)$ and chromium $(0.40)$ respectively for improved corrosion resistance).

\subsection{Laboratory rolling (TMCP)}

Controlled hot rolling experiments were carried out on a 150-ton capacity experimental rolling mill. The starting materials used were $100 \times 100 \mathrm{~mm}$ cross-section pencil ingots of a $\mathrm{Ti}-\mathrm{B}$ steel, plain-Ti steel and $\mathrm{Nb}-\mathrm{V}$ steel (see $\$ 2.1$ ). Figure 1 shows a schematic representation of a typical TMCP schedule used for the present investigation. It comprised four passes in the austenite recrystallization region $\left(1150-1025^{\circ} \mathrm{C}\right)$ and four passes in the austenite non-recrystallization region $\left(980-800^{\circ} \mathrm{C}\right)$. The total deformation in the roughing stage $(\gamma$-recrystallization zone) was $60 \%$, the degree of deformation varying between $19-23 \%$ in each pass. The total deformation in the finishing stage ( $\gamma$-non-recrystallization zone) was $70 \%$, with a cumulative rolling reduction of 3.3. Two finish rolling temperature (FRT), 800 and $850^{\circ} \mathrm{C}$ were used, followed by spray water cooling (SWC) or air cooling (AC). The cooling rate for SWC was estimated to be around $10^{\circ} \mathrm{C} / \mathrm{sec}$.

\subsection{Hot deformation (simulated TMCP)}

Controlled hot deformation studies were conducted using an MTS-458 machine modified for deformation under constant true strain rate conditions. From plates 


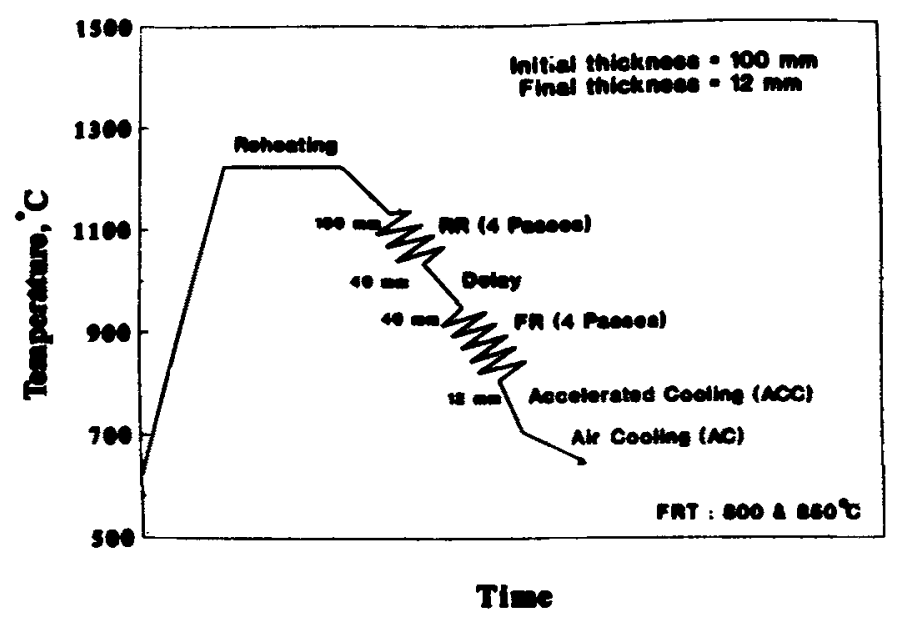

Figure 1. Schematic representation of a typical TMCP schedule used for the present investigation.

(figure 1), steel specimens were machined having a height of $15 \mathrm{~mm}$ and a diameter of $10 \mathrm{~mm}(\mathrm{~h} / \mathrm{d}$ ratio $=1.5)$. The specimens were sealed in evacuated quartz tubes. To further minimize any oxidation effects, these quartz tubes were filled with dry argon. The total pressure of each sealed tube was measured at 100 millitorr. The specimens were homogenized at $1200^{\circ} \mathrm{C}$ for $30 \mathrm{~min}$. This ensured that the carbides, nitrides and carbonitrides of titanium and boron to go into solid solution. After the austenitizing treatment, the specimens were quenched in a bath of ice-water mixture. This treatment ensured that the composition of the austenite at $1200^{\circ} \mathrm{C}$ could be retained. The specimens were next loaded in the modified MTS-458 unit and reheated to a temperature of $1200^{\circ} \mathrm{C}$ for $3 \mathrm{~min}$. Following the austenitizing treatment, the specimens were subjected to controlled deformation at precise strain rates and temperatures followed by air cooling/water quenching. In order to monitor the specimen temperature during hot deformation, a hole of $1.6 \mathrm{~mm}$ diameter was drilled into each cylindrical specimen at mid-height. A thermocouple was embedded here at a depth of $\sim 5 \mathrm{~mm}$.

Figure 2 shows a temperature-time schematic diagram of deformation sequence used for the present study. In order to study the microstructural changes occurring during hot deformation of austenite, specimens were directly quenched (WQ1, WQ2, WQ3) at different stages of austenite conditions. The steel specimens (after hot deformation) were also air cooled to room temperature to study the evolution of the final microstructure from the austenite conditioned during hot deformation.

To simulate plate rolling conditions, a series of specimens were subjected to the following deformation schedule: (i) $1200^{\circ} \mathrm{C}-3 \mathrm{~min}-\mathrm{WQ}$, (ii) $1200-1000^{\circ} \mathrm{C}$ (33\%)5 - WQ, (iii) $1200-1000^{\circ} \mathrm{C}(33 \%) 5-\mathrm{ACRT}$, (iv) $1200-1000^{\circ} \mathrm{C}$ (33\%) $5-800$ (50) $20-W Q$ and (v) $1200-1000^{\circ} \mathrm{C}$ (33\%) 5-800 (50) $20-$ ACRT.

To elaborate, let us take (v) as an example. Here the speciman was austenitized at $1200^{\circ} \mathrm{C}$ for $3 \mathrm{~min}$, forced air cooled at a rate of $30^{\circ} \mathrm{C} \mathrm{s}^{-1}$ to a temperature of $1000^{\circ} \mathrm{C}$, deformed at $1000^{\circ} \mathrm{C}\left(\varepsilon=33 \%, \dot{\varepsilon}=5 \mathrm{~s}^{-1}\right)$, forced air cooled to $800^{\circ} \mathrm{C}$, deformed at $800^{\circ} \mathrm{C}\left(\varepsilon=50 \%, \dot{\varepsilon}=20 \mathrm{~s}^{-1}\right)$ and air cooled to room temperature. 
To simulate the hot strip rolling conditions, a series of specimens were subjected to the following TMCP schedule: (i) $1200-1000^{\circ} \mathrm{C}(33 \%) 20-\mathrm{WQ}$, (ii) $1200-1000^{\circ} \mathrm{C}$ (33\%) $20-\mathrm{ACRT}$, (iii) $1200-1000^{\circ} \mathrm{C}(33 \%) 20-\mathrm{C}(600)-\mathrm{ACRT}$, (iv) $1200-1000^{\circ} \mathrm{C}$ (33\%) $20-800$ (50) $20-W Q$ and (v) $1200-1000^{\circ} \mathrm{C}(33 \%) 20-800$ (50) $20-$ ACRT.

To cite an example, experiment (iii) represents austenitization at $1200^{\circ} \mathrm{C}$ followed by forced air cooling to a temperature of $1000^{\circ} \mathrm{C}$, deformation at $1000^{\circ} \mathrm{C}(\varepsilon=33 \%$, $\dot{\varepsilon}=20 \mathrm{~s}^{-1}$ ), air cooling to $600^{\circ} \mathrm{C}$, coiling at $600^{\circ} \mathrm{C}$ for $2 \mathrm{~h}$ followed by air cooling to room temperature.

\subsection{Tempering treatment}

Here thermomechanically processed $12 \mathrm{~mm}$ plates (see figure 1 and $\S 2.2$ ) were subjected to tempering treatments at 550,600 and $650^{\circ} \mathrm{C}$ for $15 \mathrm{~min}$ followed by air cooling to room temperature.

\subsection{Metallography}

Longitudinal sections of the hot deformed specimens and hot rolled/tempered plates were etched with $2 \%$ nital and observed under a Reichert optical microscope. To distinguish between bainite and martensite, sodium metabisulfite-picral solution was used as the etchant. The volume fraction of second phases was estimated using a Leitz quantimet. The microhardness values of the different phases were determined using a MM6 Leitz microscope as a supplementary measure to distinguish between them.

Thin foils for electron microscopy was made using a twin jet polisher with $5 \%$ perchloric-glacial acetic acid solution and studied under a JEOL $4000 \mathrm{EX}$ microscope.

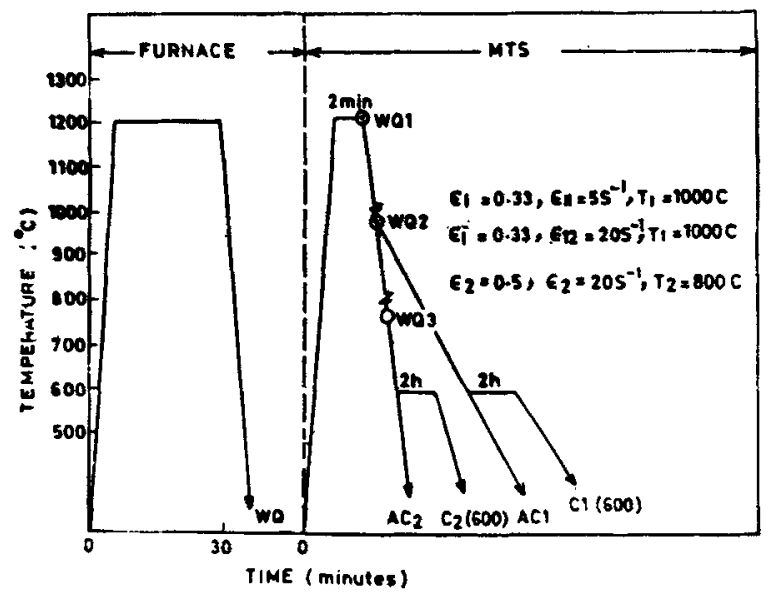

Figure 2. Temperature-time schematic diagram of deformation sequence for TMCP studies. 


\subsection{Property evaluation}

Tensile samples were prepared as per ASTM-10 (PA-370) specification and tested on an Instron machine at a strain rate of $6.6 \times 10^{-4} \mathrm{~s}^{-1}$. Standard Charpy V-notch samples were prepared and tested at room temperature, $0,-20,-40,-60,-80$ and $-100^{\circ} \mathrm{C}$ for impact energy (IE). The temperature rise during testing was within $2^{\circ} \mathrm{C}$.

\section{Results and discussion}

\subsection{Hot deformation of austenite}

The present investigation looked into the influence of deformation (strain) in the austenite region $\left(-1000^{\circ} \mathrm{C}\right)$ and deformation in the austenite non-recrystallization region $\left(\sim 800^{\circ} \mathrm{C}\right.$ ) at strain rates of $5 \mathrm{~s}^{-1}$ (to simulate plate rolling) and $20 \mathrm{~s}^{-1}$ (to simulate hot strip rolling) on the austenite grain structure and grain size of a steel microalloyed with titanium and boron.

Figure 3 shows an optical micrograph of the steel austenitized at $1200^{\circ} \mathrm{C}$ and ice-water quenched, revealing packets of lath martensite within prior austenite grains. The average prior austenite grain size was estimated to be $125 \mu \mathrm{m}$. Figures $4 \mathrm{a}, \mathrm{b}$ depict the microstructural changes occurring during plate rolling in the $\gamma$-recrystallization zone. Deformation $\left(\varepsilon=33 \%, \dot{\varepsilon}=5 \mathrm{~s}^{-1}\right)$ at $1000^{\circ} \mathrm{C}$ followed by ice water quenching (figure $4 \mathrm{a})$ resulted in a finer austenite grain size $(\sim 60 \mu \mathrm{m})$. A change in the cooling rate from iced-water quenching to air cooling led to the formation of a typical acicular ferrite microstructure (figure 4b).

The microstructural changes occurring during simulated hot strip rolling in the $\gamma$-recrystallization zone was found to be similar to that observed for plate rolling. The austenite grain size after deformation $\left(\varepsilon=33 \%, \dot{\varepsilon}=20 \mathrm{~s}^{-1}\right)$ at $1000^{\circ} \mathrm{C}$ was estimated to be $53 \mu \mathrm{m}$. This is similar to that obtained in the case of plate rolling in the $\gamma$-recrystallization zone (figure 4a). A change in cooling rate (from water quenching to air cooling) led to a acicular ferrite structure. Here, a uniform dispersion of a second phase, both at ferrite grain boundaries and within ferrite grains can be seen. This was not so clearly evident in figure $4 \mathrm{~b}$.

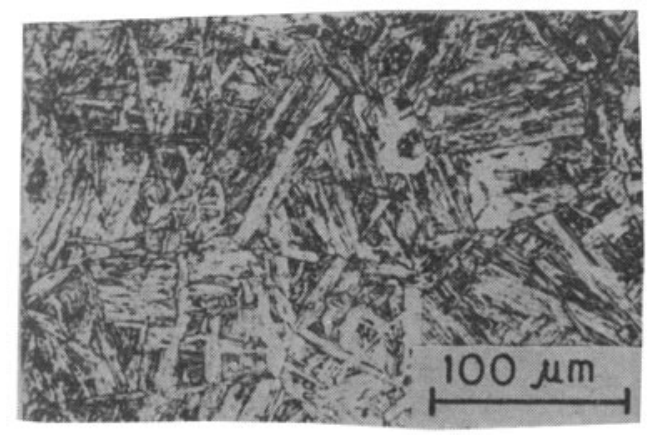

Figure 3. Optical micrograph of a Ti-B stcel $\left(1200^{\circ} \mathrm{C}-\mathrm{WQ}\right)$ revealing prior austenite grains. 


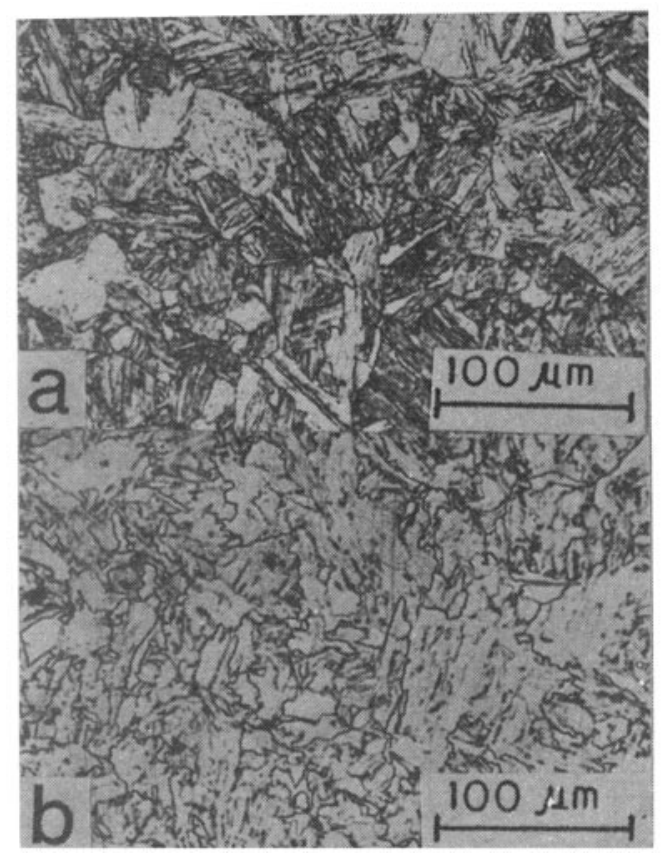

Figure 4. Microstructural changes occurring under simulated plate rolling condition $\left(\varepsilon=33 \%, \dot{\varepsilon}=5 \mathrm{~s}^{-1}, \mathrm{~T}=1000^{\circ} \mathrm{C}\right.$ ) for a Ti-B steel followed by (a) ice-water quenching and (b) air cooling.

It is of interest to note the nature of the flow stress curves of austenite for each deformation schedule, i.e. for simulated plate $\left(\dot{\varepsilon}=5 \mathrm{~s}^{-1}\right)$ and hot strip $\left(\dot{\varepsilon}=20 \mathrm{~s}^{-1}\right)$ rolling conditions. The true stress-true strain curves. would represent concurrent processes of strain hardening and restoration (softening) that takes place in a single hit or double hit tests, with a predetermined time delay $\left(t_{d}\right)$ between the hits.

Figure 5 represents true stress-true strain curves of austenite obtained for double hit experiments under following conditions: (a) $1200-1000^{\circ} \mathrm{C}(33 \%)$ 5-800 (50\%) 20 (simulating plate rolling) and (b) $1200-1000^{\circ} \mathrm{C}(33 \%) 20-800$ (50\%) 20 (simulating hot strip rolling). Simulated hot strip rolling led to higher flow stress values of austenite as compared to that obtained for simulated plate rolling. This is expected to lead to a higher strength level of a hot strip product as compared to a plate product, deformed under identical conditions. Moreover, it may also be noted that the flow stress curves (both for simulated plate rolling and hot strip rolling) exhibits continuous work hardening of the austenite with increasing strain. It may be interpreted that the dominant restoration process associated with hot deformation of austenite under the above conditions is dynamic recovery (Tanaka 1981; HSLA Steels 1988).

\subsection{Acicular ferrite microstructure}

The demand for steels of strength and toughness levels beyond those offered by conventional ferrite-pearlite steels has necessitated considerable attention to be 
directed towards control rolled transformation strengthened acicular ferrite or bainitic steels (Kim and Thomas 1983; Lander et al 1983; Shiga et al 1983; Kim et al 1985; Sanak Mishra et al 1986; Abe et al 1988; Yoshikawa et al 1988; Datta et al 1991). Thus Kim and Thomas (1983) developed dual phase microstructure through control rolling and quenching of Fe-Mn-C steel. Shiga et al (1983) and Lander et al (1983) showed the way to obtain ferrite-bainite-martensite microstructures with strength and toughness properties equivalent to $\mathrm{X} 70 / \mathrm{X} 80$ grade linepipe steels using $\mathrm{C}-\mathrm{Nb}$ and $\mathrm{C}-\mathrm{Mo}-\mathrm{Nb}-\mathrm{V}$ compositions. Similarly, Kim et al (1985) reported the development of acicular ferrite microstructure in a directly quenched $\mathrm{Nb}$ containing low carbon steel. The present investigation on the other hand reports development of acicular ferrite microstructure in control rolled and quenched Ti-microalloyed low carbon steels.

Figure 6 shows an optical micrograph of a plain-Ti steel finish rolled at $750^{\circ} \mathrm{C}$, exhibiting typical acicular ferrite microstructure with small amount of bainite

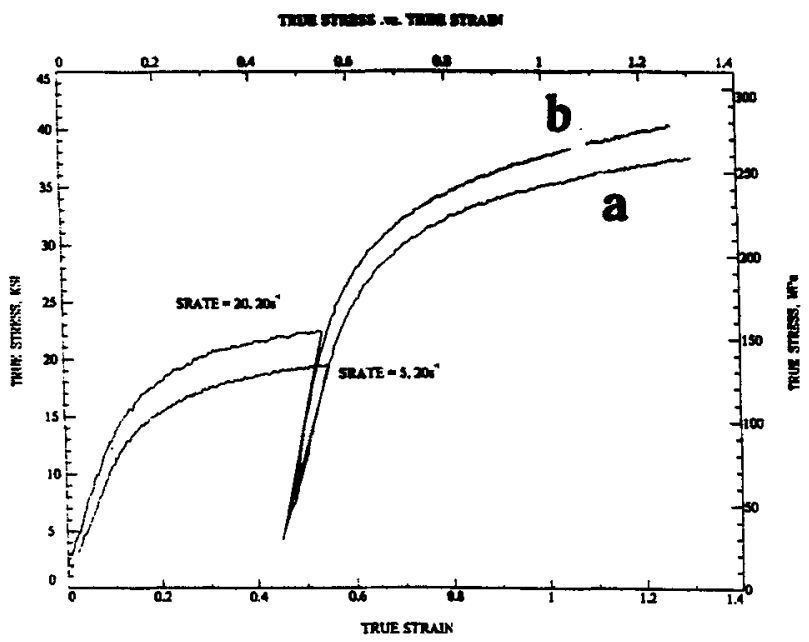

Figure 5. Flow stress curves of austenite for (a) simulated plate rolling and (b) simulated hot strip rolling under identical conditions.

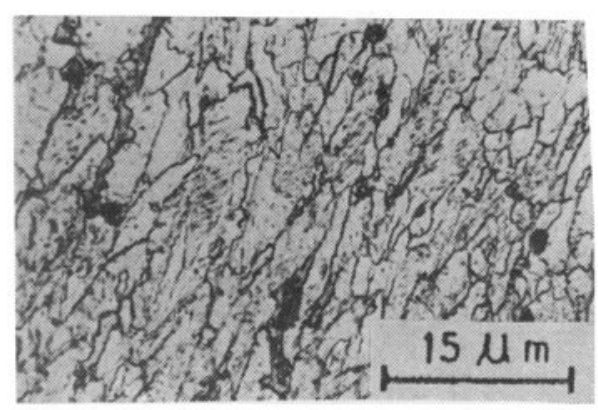

Figure 6. Optical micrograph of plain-Ti steel (FRT, $750^{\circ} \mathrm{C}$ ) exhibiting a typical acicular ferrite microstructure. 
dispersed within the matrix. When the FRT was increased to either 850 or $900^{\circ} \mathrm{C}$, the microstructure changed from acicular to polygonal ferrite with small amounts of bainite and martensite (figure $7, F R T, 900^{\circ} \mathrm{C}$ ). The influence of TMCP parameters on the microstructure, volume fraction of second phase and ferrite grain size is shown in table 1. The volume fraction of second phase increased from 7.2 to $17.6 \%$ with an increase in FRT from 750 to $900^{\circ} \mathrm{C}$. The average ferrite grain size was found to be insensitive to FRT, being marginally lower $(4.2 \mu \mathrm{m})$ in case of FRT of $900^{\circ} \mathrm{C}$. The average microhardness values for polygonal ferrite, bainite and martensite obtained for FRT of $900^{\circ} \mathrm{C}$ were 165,251 and $341 \mathrm{HV}$ respectively. The acicular ferrite microstructure (FRT, $750^{\circ} \mathrm{C}$ ) yielded the best combination of properties (YS, $520 \mathrm{MPa}$; UTS, $660 \mathrm{MPa}$; $\varepsilon_{\mathrm{T}}, 20 \%$; CIE $\left.\left(-20^{\circ} \mathrm{C}\right), 52 \mathrm{~J}\right)$.

Figure 8 shows a transmission electron micrograph of a plain Ti steel finish rolled at $750^{\circ} \mathrm{C}$, showing laths of acicular ferrite. A moderately high dislocation density was found within the acicular ferrite $\left(\sim 9 \times 10^{9} \mathrm{~cm}^{-2}\right)$. This was estimated using the linear intercept method developed by Ham (1961). The high yield strength $(520 \mathrm{MPa})$ for the steel finish rolled at $750^{\circ} \mathrm{C}$ can be attributed to a fine ferrite grain size $(\sim 5 \mu \mathrm{m})$ and a moderately high dislocation density of the acicular ferrite.

Figure 9 shows a TEM micrograph of a plain-Ti steel finish rolled at $900^{\circ} \mathrm{C}$ exhibiting a packet of lath martensite formed at a triple point junction of ferrite. A higher tensile strength of this steel (UTS, 698. MPa) as compared to the acicular ferrite steel (FRT, $750^{\circ} \mathrm{C}$, UTS, $660 \mathrm{MPa}$ ) may be related to formation of martensite and higher overall volume fraction of second phase (17.6\%).

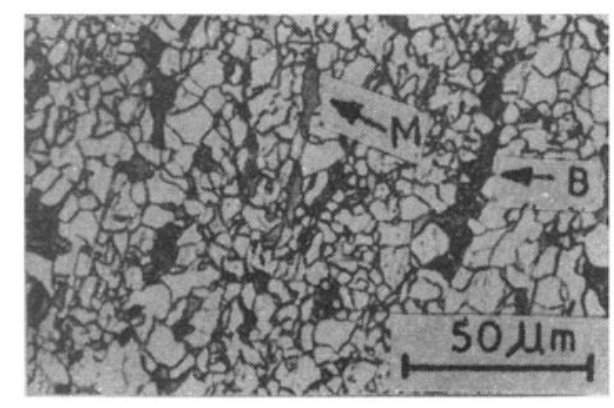

Figure 7. Optical micrograph of plain-Ti steel (FRT, $900^{\circ} \mathrm{C}$ ) showing polygonal ferrite with small amounts of second phases comprising bainite and martensite.

Table 1. Characterization of microstructure for a plain-Ti steel subjected to different processing conditions.

\begin{tabular}{|c|c|c|c|c|c|}
\hline \multirow[b]{2}{*}{ Steel type } & \multirow[b]{2}{*}{$\mathrm{FRT}\left({ }^{\circ} \mathrm{C}\right)$} & \multicolumn{2}{|c|}{ Microsi"ucture } & \multirow{2}{*}{$\begin{array}{l}\text { Volume }(\%) \text { of } \\
\text { second phase }\end{array}$} & \multirow{2}{*}{$\begin{array}{l}\text { Ferrite grain } \\
\text { size }(\mu \mathrm{m})\end{array}$} \\
\hline & & Primary phase & Secondary phase & & \\
\hline \multirow[t]{3}{*}{ Plain-Ti } & 750 & Acicular ferrite & Bainite & $7 \cdot 2$ & $5 \cdot 1$ \\
\hline & 850 & Polygonal ferrite & Bainite & - & - \\
\hline & 900 & Polygonal ferrite & Bainite and martensite & 17.6 & $4 \cdot 2$ \\
\hline
\end{tabular}




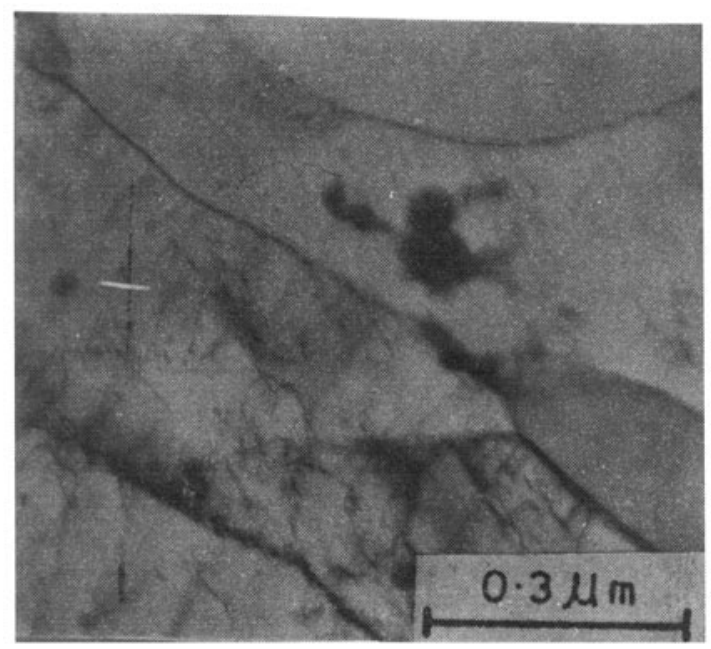

Figure 8. TEM micrograph showing acicular ferrite laths with high dislocation density for plain-Ti steel (FRT, $750^{\circ} \mathrm{C}$ ).

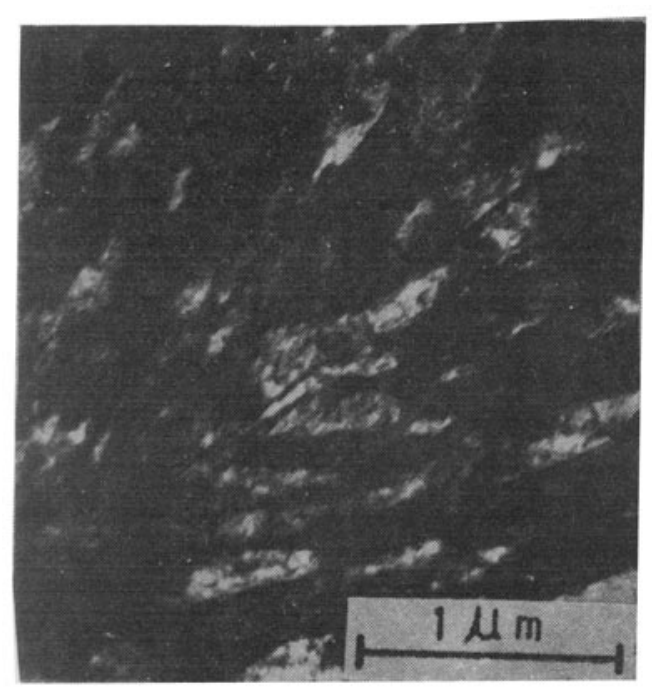

Figure 9. TEM micrograph showing dislocated laths of martensite formed at triple point junctions of ferrite in plain-Ti steel (FRT, $900^{\circ} \mathrm{C}$ ).

\subsection{Bainitic microstructure}

In recent years, a lot of emphasis has been directed towards development of Ti-microalloyed HSLA steels containing small additions of boron and involving controlled rolling and accelerated cooling (Pressouyre et al 1985; Tamehiro et al 1987; Krishnadev et al 1988). The present work discusses the influence of processing variables such as austenitizing time, FRT and cooling rate on the microstructure 
and properties of a control rolled Ti-B microalloyed HSLA steel (Ramaswamy et al 1991; Datta et al 1993).

The microstructure, ferrite grain size and volume fraction of second phase obtained for the Ti-B steel subjected to different processing conditions are listed in table 2 . It may be noted that the austenitizing time ( $1 \mathrm{~h}$ and $3 \mathrm{~h}$ ) does not have any significant influence on the product microstructure, ferrite grain size and volume\% of second phase.

The cooling rate was found to have a significant influence on the microstructure and properties of the Ti-B steel. A change in cooling rate from air to spray water cooling led to a change in microstructure from ferrite-pearlite to ferrite-bainite. Figures $10 \mathrm{a}$ and $\mathrm{b}$ are optical micrographs of steels finish rolled at 850 and $800^{\circ} \mathrm{C}$ respectively, followed by spray water cooling. Finish rolling at $850^{\circ} \mathrm{C}$ resulted in a coarse bainitic structure while a lower FRT of $800^{\circ} \mathrm{C}$ yielded a polygonal ferrite-massive bainite structure. The above classification into coarse bainite (Bc) and massive bainite $(\mathrm{Bm})$ structures is in accordance to that reported by Yoshikawa et al (1988).

Figures 11a and b represent TEM photomicrographs taken from a polygonal ferrite-massive bainite (800-SWC) steel. The high dislocation density within the ferrite and fine precipitates pinning the dislocations may be noted (figure 11a). The dislocations appear mostly in tangled form. Figure $11 \mathrm{~b}$ reveals the substructure within a massive bainite region. Presence of a second phase (martensite/retained austenite) can be seen at the interface of ferrite laths in addition to finer carbide precipitation within the laths. Similar type of substructure has been reported by Guoquing and Weixun (1985). Energy dispersive analysis of precipitates in the polygonal ferrite region of the same steel was also carried out. Analysis of the coarse precipitates revealed them to be TiS type while the finer precipitates were found to be either $\mathrm{Ti}_{2} \mathrm{~S}$ or $\mathrm{Ti}_{4} \mathrm{~S}_{2} \mathrm{C}_{2}$ compounds.

Figures 12a and $\mathrm{b}$ show the influence of processing parameters, microstructure and tensile strength on the impact transition temperature. The transition temperature increased linearly from $-72^{\circ} \mathrm{C}$ (800-AC, ferrite pearlite) to $-35^{\circ} \mathrm{C}(850-\mathrm{SWC}$, coarse bainite). Thus, the ferrite-pearlite steel exhibited superior toughness properties to

Table 2. Characterization of mícrostructure for a Ti-B steel subjected to different processing conditions.

\begin{tabular}{|c|c|c|c|c|c|c|c|}
\hline & rocess & ng var & & & & & \\
\hline $\begin{array}{l}\text { Austeni- } \\
\text { tization } \\
\text { temp. }\end{array}$ & Time & FRT & Cooling & Microst & Ictures & Ferrite orain & Volume (\%) \\
\hline & (h) & (C) & rate & Primary phase & Secondary phase & size $(\mu \mathrm{m})$ & phase $\left(V_{\mathrm{f}}\right)$ \\
\hline $1200-$ & & 850 & $\mathrm{AC}$ & Polygonal ferrite & Pearlite & 6.0 & $6 \cdot 0$ \\
\hline $1200-$ & & 850 & SWC & Ferrite & Coarse bainite & - & - \\
\hline $1200-$ & & 800 & $\mathrm{AC}$ & Polygonal ferrite & Pearlite & 8.5 & $7 \cdot 1$ \\
\hline $1200-$ & & 800 & SWC & Polygonal ferrite & Massive bainite & $8 \cdot 5$ & 29.6 \\
\hline $1200-$ & & 850 & $\mathrm{AC}$ & Polygonal ferrite & Pearlite & $9 \cdot 0$ & 6.0 \\
\hline $1200-$ & & 850 & SWC & Ferrite & Coarse bainite & - & - \\
\hline $1200-$ & & 800 & $\mathrm{AC}$ & Polygonal ferrite & Pearlite & 8.8 & $3 \cdot 7$ \\
\hline $1200-$ & 3 & 800 & SWC & Polygonal ferrite & Massive bainite & $7 \cdot 6$ & $32 \cdot 0$ \\
\hline
\end{tabular}

AC: Air cooling; SWC: Spray water cooling. 


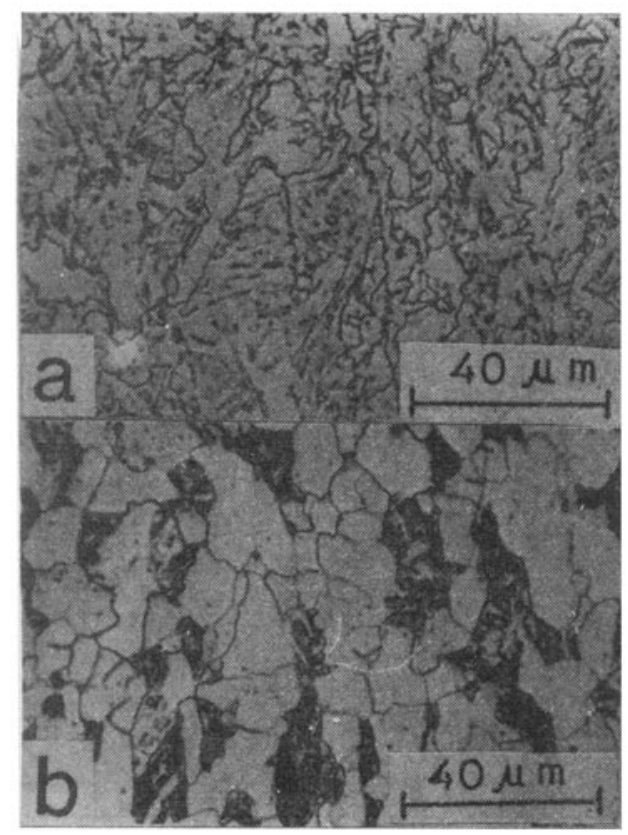

Figure 10. Optical micrographs showing typical (a) coarse bainite and (b) massive bainite structure for Ti-B steels rolled at 850 and $800^{\circ} \mathrm{C}$ respectively, followed by spray water cooling.

that of bainitic (coarse and massive) structures. The strength levels however, are significantly higher for the bainitic steels $(600-630 \mathrm{MPa})$ as compared to the ferrite-pearlite steels $(430-460 \mathrm{MPa})$.

\subsection{Microstructural changes accompanying tempering}

The present study deals with a thermomechanically processed low carbon $\mathrm{Nb}-\mathrm{V}$ steel subjected to short tempering treatments. The microstructural and substructural changes associated with tempering at $550-650^{\circ} \mathrm{C}$ have been discussed (Datta et al 1994).

Figure 13a shows a typical bainitic microstructure obtained for the steel finish rolled at $850^{\circ} \mathrm{C}$ and spray water cooled. The volume fraction of ferrite and bainite was estimated to be 0.17 and 0.83 respectively (table 3 ). Figures $13 \mathrm{~b}-\mathrm{d}$ depict the microstructural changes upon tempering at 550,600 and $650^{\circ} \mathrm{C}$. It may be seen that the volume fraction of ferrite progressively increases with increasing tempering temperature, attaining a maximum value of 0.34 at $650^{\circ} \mathrm{C}$ (table 3 ).

Finish rolling of the steel at $800^{\circ} \mathrm{C}$ followed by spray water cooling led to a polygonal ferrite-massive bainite microstructure. Similar structural features were reported by Datta et al (1993) (see figure 10b) for a thermomechanically processed Ti-B steel. Tempering of this steel at 550,600 and $650^{\circ} \mathrm{C}$ led to a finer polygonal ferrite-bainite structure. Formation of fine recrystallized freshly nucleated ferrite grains could be observed. Though the overall microstructure appeared finer, there 


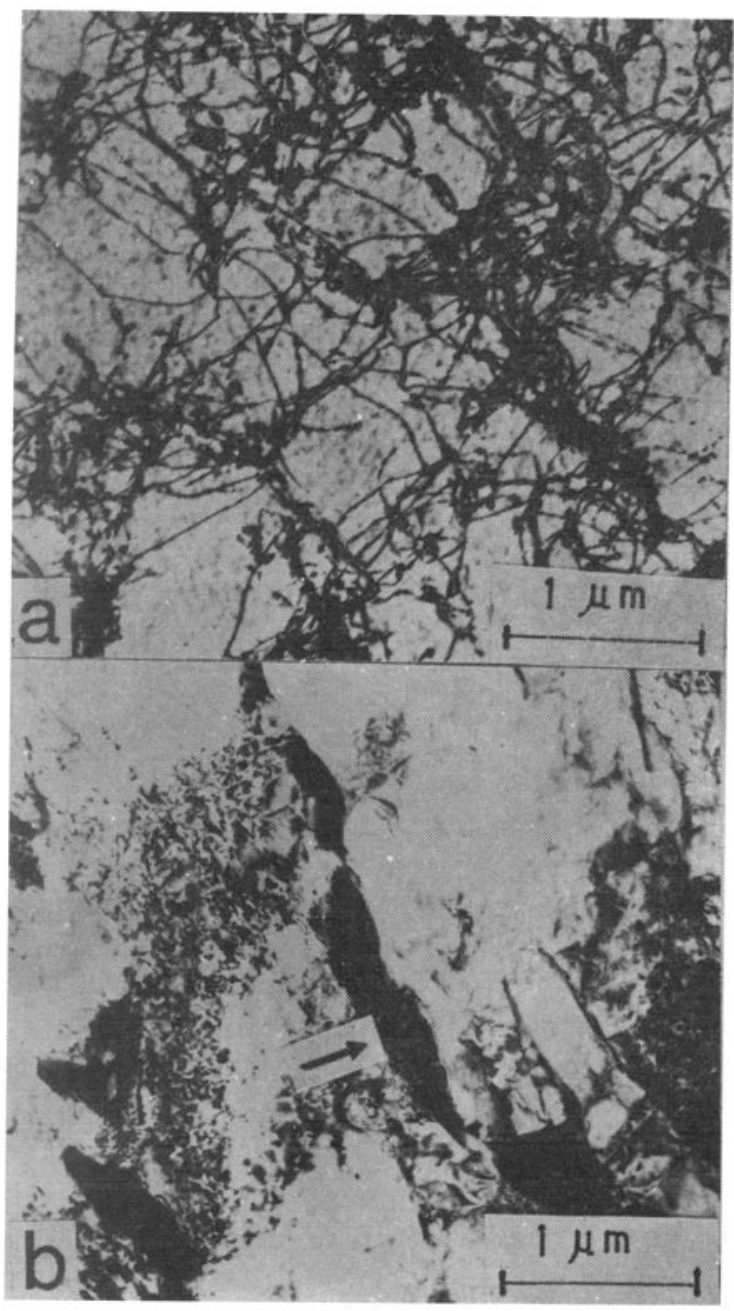

Figure 11. TEM micrographs taken from a ferrite massive bainite steel showing (a) high density of tangled dislocations within ferrite and (b) substructure within massive bainite.

was no significant change in the volume fractions of ferrite and bainite (table 3 ). The ferrite and bainite were estimated to be roughly $70-75 \%$ and $25-30 \%$ respectively, irrespective of the processing condition.

Figure 14a shows a transmission electron micrograph of a as-rolled steel finish rolled at $850^{\circ} \mathrm{C}$. Elongated ferrite laths can be seen surrounded by dark regions which may be retained austenite (RA) or martensite (M). Figure $14 \mathrm{~b}$ shows the selected area diffraction (SAD) pattern taken from the dark region (indicated by arrow) and its interpretation. In this case the $S A D$ pattern indicates the presence of martensite.

Tempering of the steel at temperatures 600 and $650^{\circ} \mathrm{C}$ led to the decomposition of martensite and formation of carbide precipitates at the interface of ferrite laths. A typical example is shown in figure $15 \mathrm{a}$, which represents a steel $\left(850^{\circ} \mathrm{C}\right.$ FRT-SWC) 


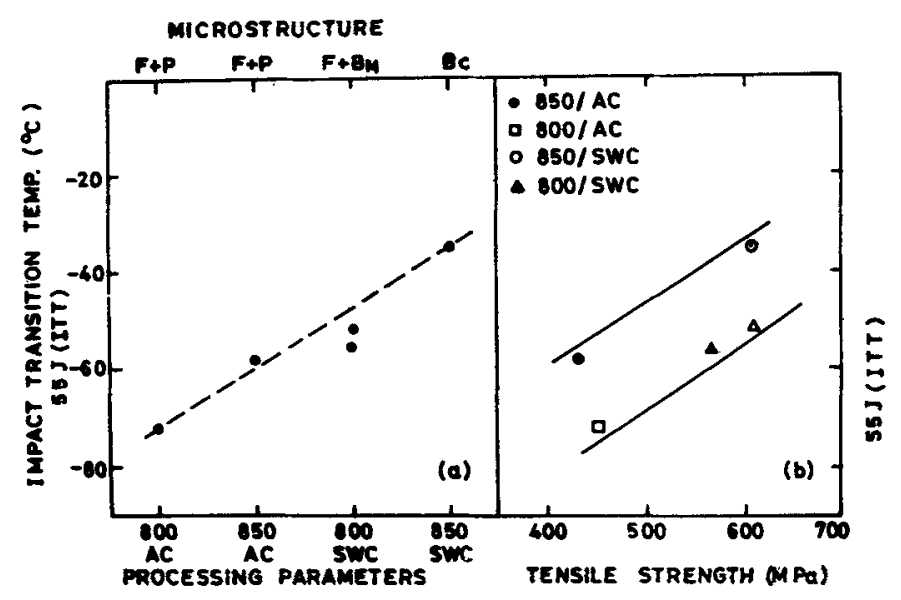

Figure 12. Influence of (a) processing parameters, microstructure and (b) tensile strength on impact transition temperature for a Ti-B steel.

tempered at $650^{\circ} \mathrm{C}$. Selected area diffraction studies (figure $15 \mathrm{~b}$ ) revealed that these elongated carbides are essentially cementite $\left(\mathrm{Fe}_{3} \mathrm{C}\right)$. The formation of $\mathrm{Fe}_{3} \mathrm{C}$ within the decomposed martensite upon tempering at 600 and $650^{\circ} \mathrm{C}$ may lead to overall softening of the steel and concomitant improvement in charpy upper shelf energy (USE) and ductile brittle transition temperature, as observed in the present investigation (figure 16).

Thermomechanical controlled processing led to the formation of fine precipitates in the as-rolled steel. These precipitates remained fine even after tempering at $550^{\circ} \mathrm{C}$. Figure $17 \mathrm{a}$ shows such precipitates within ferrite for the steel finish rolled at $850^{\circ} \mathrm{C}$ followed by tempering at $550^{\circ} \mathrm{C}$. SAD studies (figure $17 \mathrm{~b}$ ) revealed that these precipitates are $\mathrm{Nb}-\mathrm{V}$ (C) type ranging in size between $10-20 \mathrm{~nm}$.

Table 3 shows the Vickers hardness values of the $\mathrm{Nb}-\mathrm{V}$ steel subjected to different processing conditions. The microhardness values of the different phases are also shown. The as-rolled hardness value of the steel finish rolled at $850^{\circ} \mathrm{C}$ is found to be higher $(289 \mathrm{HV})$ compared to the steel finish rolled at $800^{\circ} \mathrm{C}(266$ HV). This is in spite of the fact that the microhardness value of the bainite formed upon cooling from $850^{\circ} \mathrm{C}(401 \mathrm{HV})$ is significantly lower compared to that formed from $800^{\circ} \mathrm{C}(560 \mathrm{HV})$. A possible explanation to the above may be related to the volume fraction of different phases (ferrite and bainite). A higher volume fraction of bainite $(0.83)$ for the steel finish rolled at $850^{\circ} \mathrm{C}$ may have ensured a higher overall hardness value $(289 \mathrm{HV})$ as compared to the steel finish rolled at $800^{\circ} \mathrm{C}$ $\left(V_{\mathrm{B}}: 0.30,266 \mathrm{HV}\right)$.

Figure 16 shows the influence of tempering temperature on the yield strength (YS), ultimate tensile strength (UTS), elongation $\left(\varepsilon_{\mathrm{T}}\right)$, hardness, Charpy impact energy (CIE) and $55 \mathrm{~J}$ impact transition temperature for the steel finish rolled at $850^{\circ} \mathrm{C}$. The yield strength increased initially, reached a maxima at $600^{\circ} \mathrm{C}$ and decreased with higher tempering temperature. The UTS decreased linearly with increasing tempering temperature. The elongation values decreased initially at $550^{\circ} \mathrm{C}$ $(12.3 \%)$, but improved thereupon with higher tempering temperatures $(15.4 \%$ at 


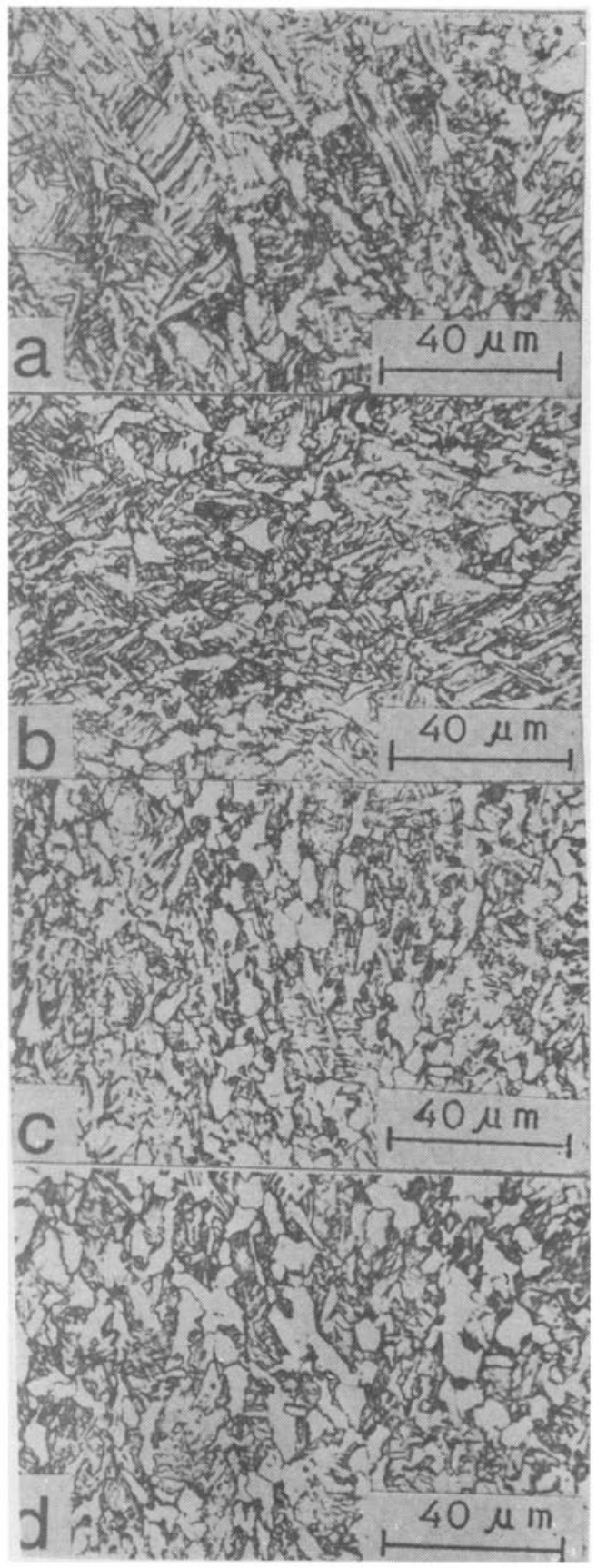

Figure 13. Optical micrographs showing the changes in microstructure with tempering for a $\mathrm{Nb}-\mathrm{V}$ steel (a) as-rolled, $850-\mathrm{SWC}$, (b) tempered at $550^{\circ} \mathrm{C}$, (c) tempered at $600^{\circ} \mathrm{C}$ and (d) tempered at $650^{\circ} \mathrm{C}$. 
Table 3. Typical hardness, microhardness and volume fraction values of different phases for a $\mathrm{Nb}-\mathrm{V}$ steel subjected to different processing conditions.

\begin{tabular}{|c|c|c|c|c|c|c|c|}
\hline \multicolumn{3}{|c|}{ Processing details } & \multirow{3}{*}{$\begin{array}{c}\text { Vicker's } \\
\text { hardness } \\
\text { (HV) }\end{array}$} & \multirow{2}{*}{\multicolumn{2}{|c|}{$\begin{array}{l}\text { Mictohardness values } \\
\text { (HV) }\end{array}$}} & \multirow{2}{*}{\multicolumn{2}{|c|}{$\begin{array}{l}\text { Volume fraction of } \\
\text { ferrite/bainite }\end{array}$}} \\
\hline \multirow{2}{*}{$\begin{array}{l}\text { FRT } \\
\left({ }^{\circ} \mathrm{C}\right)\end{array}$} & \multirow{2}{*}{$\begin{array}{l}\text { Cooling } \\
\text { rate }\end{array}$} & \multirow{2}{*}{$\begin{array}{l}\text { Tempering } \\
\text { temp. }\left({ }^{\circ} \mathrm{C}\right)\end{array}$} & & & & & \\
\hline & & & & $F$ & B & $\mathbf{F}$ & B \\
\hline 850 & SWC & (As-rolled) & 289 & 311 & 401 & 0.17 & 0.83 \\
\hline 850 & SWS & 550 & 280 & 228 & 356 & 0.22 & 0.78 \\
\hline 850 & SWC & 600 & 237 & 231 & 300 & 0.28 & 0.72 \\
\hline 850 & SWC & 650 & 223 & 231 & 334 & 0.34 & 0.66 \\
\hline 800 & SWC & (As-rolled) & 266 & 270 & 560 & 0.70 & 0.30 \\
\hline 800 & SWC & 550 & 232 & 220 & 397 & 0.75 & 0.25 \\
\hline 800 & SWC & 600 & 222 & 216 & 307 & 0.71 & 0.29 \\
\hline 800 & SWC & 650 & 211 & 228 & 295 & 0.70 & 0.30 \\
\hline
\end{tabular}
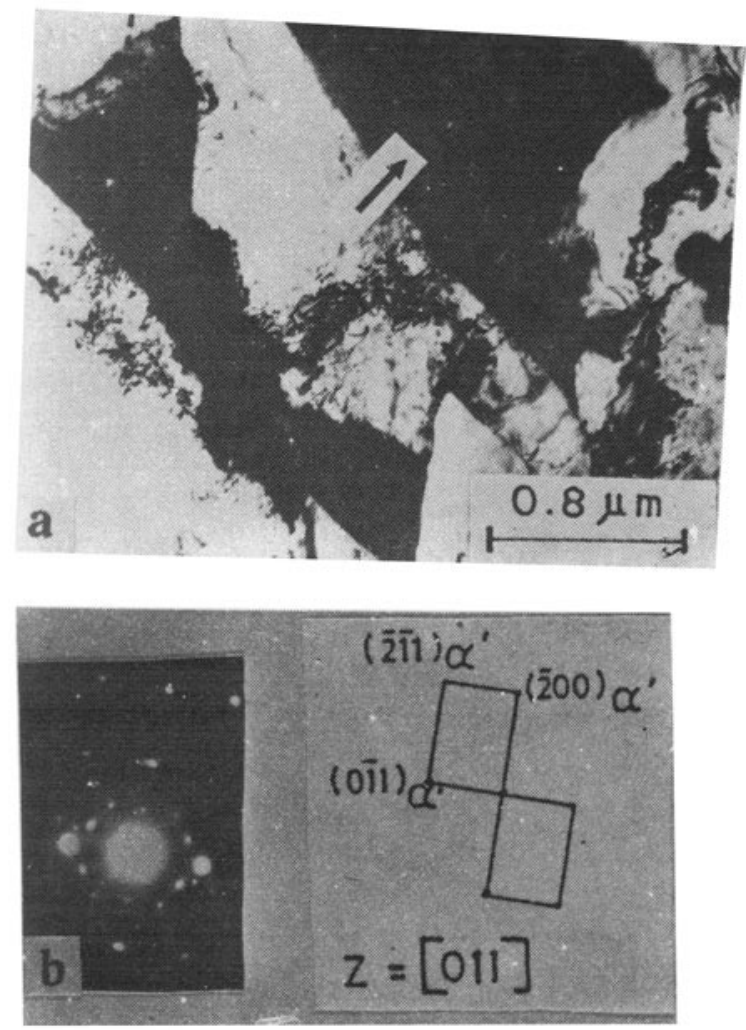

Figure 14. TEM micrograph from a bainitic steel (FRT, $850^{\circ} \mathrm{C}$, SWC) showing (a) ferrite laths surrounded by M/RA and (b) SAD pattern from the dark area and its interpretation.

$600^{\circ} \mathrm{C}$ and $17 \%$ at $650^{\circ} \mathrm{C}$ ). The Charpy impact energy showed significant improvement. It increased two fold, from $20 \mathrm{~J}$ (as-rolled) to $44 \mathrm{~J}(650-15 \mathrm{~min})$ at $-40^{\circ} \mathrm{C}$. The 55 $J$ ITT which is a reflection of the resistance of the steel to brittle fracture improved significantly with tempering from $>\mathrm{RT}$ (room temperature) for as-rolled steel to $-26^{\circ} \mathrm{C}$ for $650^{\circ} \mathrm{C}$ tempering. Blicharski et al (1988) reported a similar behaviour 


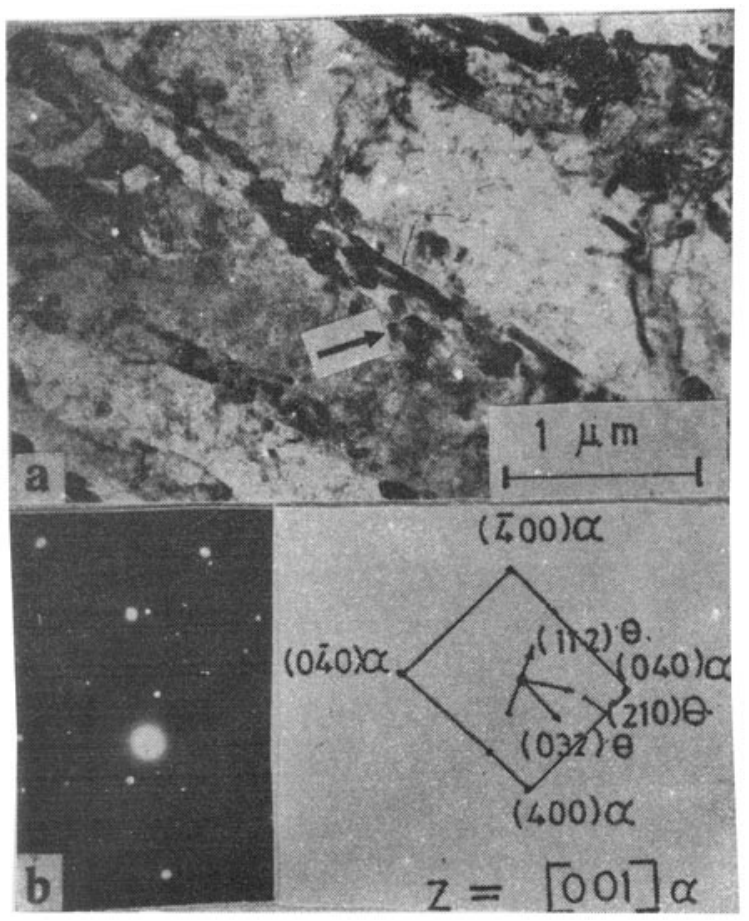

lïpure 15. IEN micrograph taken from a lempered hainutc steel (850 FRT, $650^{\circ} \mathrm{C}-15$ mon) howing (a) precipitation of cementitc $\left(\mathrm{Fc}_{3} \mathrm{C}\right)$ within the decomposed martensite and (b) S.11) pallern flom the precipitales and its interpretation.

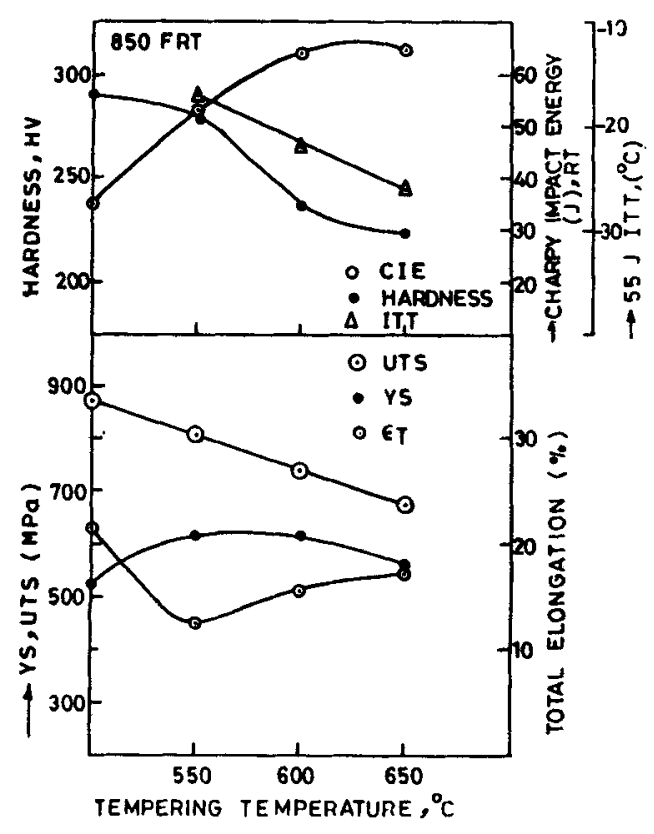

Figure 16. Influence of temperature on the strength, toughness and hardness properties of a rolled $\left(850^{\circ} \mathrm{C}\right.$ FRT) and tempered bainitic steel. 

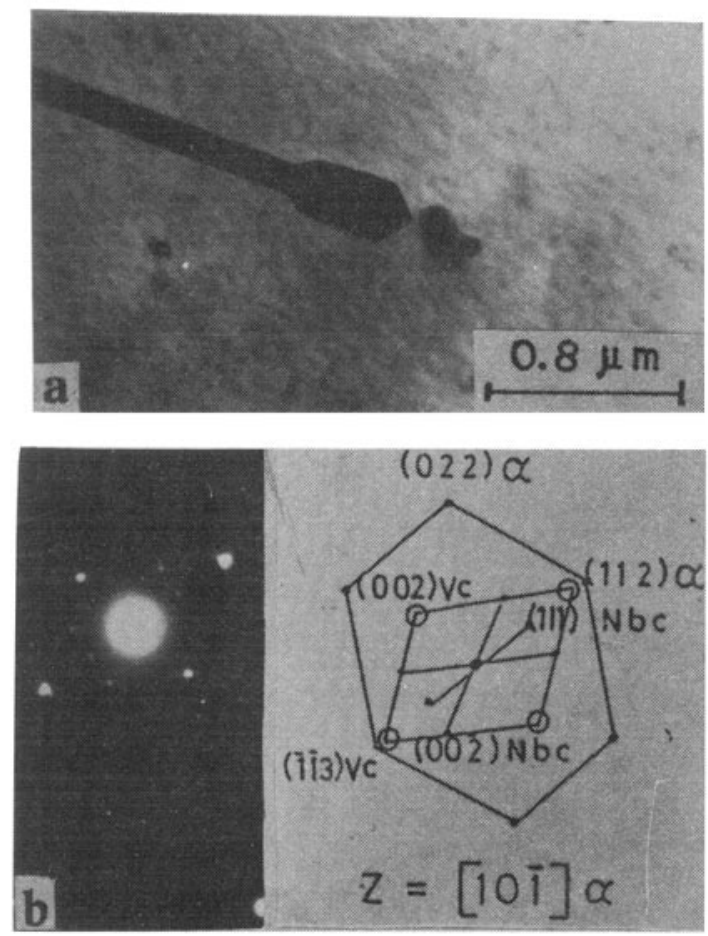

Figure 17. TEM micrograph showing (a) precipitates dispersed within ferrite and (b) SAD pattern with interpretation for a tempered $\mathrm{Nb}-\mathrm{V}$ steel (FRT, $850^{\circ} \mathrm{C}, 550^{\circ} \mathrm{C}-15 \mathrm{~min}$ ).

for tempered ULCB steels. Their results showed that ULCB steels are fairly insensitive to tempering treatments when tempered below $550^{\circ} \mathrm{C}$. Beyond $550^{\circ} \mathrm{C}$, the hardness value decreased progressively. with increasing tempering temperature indicating overall softening. The yield strength also showed slight increase initially for ULCB steels, as in our case.

\section{Summary}

\subsection{Hot deformation of austenite}

(i) The prior austenite grain size for a Ti-B steel upon austenitization at $1200^{\circ} \mathrm{C}$ was estimated to be $125 \mu \mathrm{m}$. Controlled deformation in the austenite recrystallization zone $\left(1000^{\circ} \mathrm{C}, \varepsilon=33 \%, \dot{\varepsilon}=5 \mathrm{~s}^{-1}\right.$ and $\left.20 \mathrm{~s}^{-1}\right)$ followed by water quenching both for simulated plate rolling and hot strip rolling led to a significant decrease in the austenite grain size (60 and $53 . \mu \mathrm{m}$ respectively).

(ii) A change in cooling rate from water quenching to air cooling resulted in a typical acicular ferrite microstructure.

(iii) Flow stress curves of austenite for simulated plate rolling and hot strip rolling under identical conditions revealed that the stress required for deformation of austenite is higher for hot strip rolling than that for plate rolling. 


\subsection{Acicular ferrite microstructure}

(i) A finish rolling temperature (FRT) of $750^{\circ} \mathrm{C}$ followed by water quenching resulted in an acicular ferrite microstructure (with fairly high dislocation density within the laths) for a plain-Ti microalloyed steel. A higher FRT $\left(850-900^{\circ} \mathrm{C}\right.$ ) yielded a polygonal ferrite microstructure with second phase constituents comprising bainite and martensite.

(ii) The plain- $\mathrm{Ti}$ steel finish rolled at $750^{\circ} \mathrm{C}$ (acicular ferrite) yielded the best combination of properties. Typical values of strength, ductility and impact toughness properties obtained were: YS $=529 \mathrm{MPa}$, UTS-660 MPa, $\varepsilon_{\mathrm{T}}=20 \%$ and CIE $\left(-20^{\circ} \mathrm{C}\right)-52 \mathrm{~J}$.

\subsection{Bainitic microstructure}

(i) Variation of austenitizing time $\left(1200^{\circ} \mathrm{C}, 1\right.$ and $\left.3 \mathrm{~h}\right)$ did not have any significant influence on the microstructure, grain size, volume fraction of second phase and associated mechanical properties for Ti-B steels subjected to different processing conditions.

(ii) Finish rolling at 850 and $800^{\circ} \mathrm{C}$ followed by spray water cooling resulted in ferrite-coarse bainite and polygonal ferrite-massive bainite microstructures respectively. The polygonal ferrite-massive bainite structure exhibited comparable strength level but superior ductility-toughness properties in comparison to the ferrite-coarse bainite structure.

\subsection{Microstructural changes accompanying tempering}

(i) Finish rolling at $850^{\circ} \mathrm{C}$ followed by SWC led to a predominantly bainitic microstructure with a small volume fraction of ferrite $(0 \cdot 17 \%)$. Tempering at 550 , 600 and $650^{\circ} \mathrm{C}$ led to a progressive increase in ferrite content, from $0 \cdot 17$ (as-rolled) to $0.34\left(650^{\circ} \mathrm{C}\right.$ tempered).

(ii) Finish rolling at $800^{\circ} \mathrm{C}$ followed by SWC led to a polygonal ferrite-massive bainite structure. Tempering at 550,600 and $650^{\circ} \mathrm{C}$ led to the polygonization of ferrite leading to a fine grained ferrite structure. However, the ferrite and bainite content remained unchanged, irrespective of tempering temperature.

(iii) The yield strength (YS) increased initially, reached a maxima at $600^{\circ} \mathrm{C}$ and decreased with higher tempering temperatures $\left(650^{\circ} \mathrm{C}\right)$. The tensile strength decreased progressively with increasing tempering temperature.

(iv) The bainitic structure (as-rolled) revealed packets containing laths of ferrite with a second phase (RA/M) at the interface of ferrite laths. SAD pattern of one such second phase indicated the presence of martensite. Tempering of the bainitic steel above $600^{\circ} \mathrm{C}$ led to the decomposition of the second phase (RA/M) and precipitation of cementite $\left(\mathrm{Fe}_{3} \mathrm{C}\right)$ at the ferrite lath interfaces. This was found to be associated with overall softening of the steel. 


\section{Acknowledgements}

The authors are thankful to R \& D Centre, SAIL, Ranchi and to NSF, Washington for support. The authors also wish to acknowledge the many fruitful discussions they had with Prof. Anthony De Ardo, University of Pittsburgh and Prof. Warren M Garrison Jr., Carnegie Mellon University, USA.

\section{References}

Abe K, Shimizu M, Takashima S and Kaji H 1988 Iron Steel Inst. Japan 322

Beck P A 1954 Philos. Mag. Suppl. 3245

Blicharski M R, Garcia C I, Pytel S and De Ardo A J 1988 World materials congress, Microalloyed HSLA steels conf. proc. (Ohio: ASM)

Cuddy L J 1982 Proc. int. conf. on thermomechanical processing of microalloyed austenite (Warrendale: The Met. Soc. of AIME) p. 129

Datta R, Panigrahi B K, Sanak Mishra, Ramaswamy V, Chatterjee S and Seal A K 1991 Metall. Mater. Process. 3121

Datta R, Sanak Mishra, Ramaswamy V and De Ardo A J 1993 Key engineering materials (Switzerland: Trans. Tech. Pub.) Vols. 84-85 p. 193

Datta R, Sanak Mishra and Garrison W M 1994 Int. conf. on physical metallurgy, Bombay

Fukuda M, Hashimoto T and Kunishige K 1977 Microalloying '75 (New York: Union Carbide Corp.) p. 136 Ham R K 1961 Philos. Mag. 61183

HSLA Steels 1988 Thermomechanical processing of HSLA steels (eds) I Tamura et al (London: Buttersworth Pub.) p. 119

Irani J J, Burton D, Jones J D and Rothwell A B 1967 Iron Steel Inst. London 110

Jonas $J I$ and Weiss I 1979 Metall. Sci. 13238

Jones J D and Rothwell A B 1968 Iron Steel Inst. London 78

Guoquing $\mathrm{K}$ and Weixun Y 1985 Proc. int. conf. HSLA steels (Ohio: ASM) p. 369

Kim N J and Thomas G 1983 Steels for linepipe and pipeline fittings (London: The Metals Society) p. 121

Kim N J, Yang A J and Thomas G 1985 Met. Trans. A16 471

Krishnadev M R, Dionne S, Bowker J T and McGrath J T 1988 Iron Steel Inst. Japan 511

Lander H N, Morrow J W and Coldren A P 1983 Steels for linepipe and pipeline fittings (London: The Metals Society) p. 136

Le Bon A, Rofes-Vernis J and Rossard C 1975 Metall. Sci. 936

Lucke K and Detert K 1957 Acta Metall. 5628

Lucke K and Stuwe H P 1963 Recovery and recrystallization of metals (New York: Interscience) p. 171

Pressouyre G M, Primon G, Blondeau R, Beguinot $J$ and Thomas J M 1985 Proc. int. conf. HSLA steels (Ohio: ASM) p. 335

Ramaswamy V. Datta R, Chaudhuri S K and Mishra S 1991 Proc. emerging tech for new materials and product mix of the steel industry. Materials Week '91 (Ohio: ASM) p. 261

Rothwell A B 1972 Mem. Sci. Rev. Meiall. 69413

Sanak Mishra, Chaudhuri S K, Datta R, Saxena A K and Ray S 1986 First Indo-US workshop on co-op. res. on iron and steel tech., Ranchi

Sekine $H$ and Maruyama T 1976 Trans. ISIJ 16427

Shiga C, Amano K, Hatomura T, Saito Y, Hirose K and Choji T 1983 Steels for linepipe and pipeline fittings (London: The Metals Society) p. 127

Tamehiro H, Murata M, Habu R and Nagumo M 1987 Trans. ISIJ 27130

Tanaka T 1981 Int. Metals Rev. 185

Tanaka T 1985 Proc. int. conf. on high strength low alloy steels (Port Kembla: NSW South Coast Printers) p. 7

Tanaka T, Tabata N, Hatomura T and Shiga C 1977 Microalloying '75 (New York: Union Carbide Corp.) p. 107

Underwood E E 1968 Quantitative metallography (New York: McGraw Hill) p. 77

Yoshikawa H, Kawashima $Y$ and Konno K 1988 Iron Steel Inst. Japan 487

Zheng Y, Fitzsimons G and De Ardo A J 1984 Proc. int. conf. HSLA steels: technology and applications (Ohio: ASM) p. 85 